\title{
"Time-series evidence on corporate governance in Thailand: the effect on expected stock returns"
}

\begin{tabular}{|c|c|}
\hline AUTHORS & Yosuke Kakinuma iD https://orcid.org/0000-0001-9098-9067 \\
\hline ARTICLE INFO & $\begin{array}{l}\text { Yosuke Kakinuma (2019). Time-series evidence on corporate governance in } \\
\text { Thailand: the effect on expected stock returns. Investment Management and } \\
\text { Financial Innovations, 16(3), 332-340. doi:10.21511/imfi.16(3).2019.29 }\end{array}$ \\
\hline DOI & http://dx.doi.org/10.21511/imfi.16(3).2019.29 \\
\hline RELEASED ON & Tuesday, 08 October 2019 \\
\hline RECEIVED ON & Friday, 07 June 2019 \\
\hline \multirow[t]{2}{*}{ ACCEPTED ON } & Monday, 01 July 2019 \\
\hline & $(\mathrm{cc}) \mathrm{EY}$ \\
\hline LICENSE & $\begin{array}{l}\text { This work is licensed under a Creative Commons Attribution } 4.0 \text { International } \\
\text { License }\end{array}$ \\
\hline JOURNAL & "Investment Management and Financial Innovations" \\
\hline ISSN PRINT & $1810-4967$ \\
\hline ISSN ONLINE & $1812-9358$ \\
\hline PUBLISHER & LLC "Consulting Publishing Company "Business Perspectives" \\
\hline FOUNDER & LLC “Consulting Publishing Company "Business Perspectives" \\
\hline & $\begin{array}{ll}= \pm: \\
=- \pm\end{array}$ \\
\hline NUMBER OF REFERENCES & NUMBER OF FIGURES \\
\hline 33 & 4 \\
\hline
\end{tabular}

(C) The author(s) 2022. This publication is an open access article. 


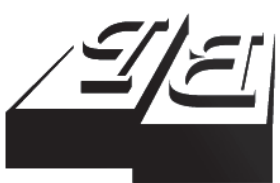

BUSINESS PERSPECTIVES

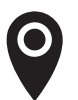

LLC "CPC "Business Perspectives" Hryhorii Skovoroda lane, 10, Sumy, 40022, Ukraine

www.businessperspectives.org

Received on: $7^{\text {th }}$ of June, 2019 Accepted on: $1^{\text {st }}$ of July, 2019

(C) Yosuke Kakinuma, 2019

Yosuke Kakinuma, Lecturer, International College, Panyapiwat Institute of Management, Nonthaburi, Thailand.

\begin{abstract}
This paper presents an empirical evidence of a time-varying relationship between corporate governance and its impacts on stock returns in Thailand. The governance grades assessed by the Thai Institute of Directors are used as governance measurement for the analysis. The parameters estimated by Fama-Macbeth regression indicate that firms with higher governance ratings generate greater expected stock returns in a long run. However, on yearly basis, the positive relationship deteriorates and loses explanatory power in the most of the tested years. The coefficients of governance ratings estimated by fixed effect regression are examined for statistical difference, which confirms that effect of corporate governance on stock returns differs year by year. While there are some distinct years that governance ratings affect stock prices positively, higher governance ratings lead to lower returns in other particular years. The both positive and negative magnitudes of corporate governance's impact on expected returns do not stay the same over time. Good governance practice at a firm does not always yield positive returns to investors.
\end{abstract}

\section{Keywords}

\section{JEL Classification}

responsible investment, corporate governance, panel data regression, emerging market

C33, G11, G38

\title{
INTRODUCTION
}

This study aims to reveal an unstable relationship between corporate governance and its effect on expected stock returns. Prior researches draw contrasting conclusions on the influence of the firms' corporate governance practices on operating performance and valuation. A theory that a good governance leads to better operating profits and increased firm values is empirically proved by Gompers et al. (2003), Drobetz et al. (2004), Bebchuk et al. (2008), and Ammann et al. (2011). On the other hand, a causal relationship between weak protection shareholder rights and lower expected stock returns is denied by Core et al. (2006) and Bhagat and Bolton (2008). Core et al. (2006) further argue that a positive relationship between corporate governance and stock returns is rather period-specific. The results of Bauer et al. (2003) support such argument and the relationship can be negative depending on the tested year. This study fills the gap by presenting empirical results that show the effects of corporate governance ratings on expected returns are inconstant and time-varying.

This paper focuses on Thailand which is home to the second largest stock market in the Southeast Asia after Singapore. The East Asian Financial Crisis in 1997 started in Thailand, and Zhuang et al. (2000) blame poor corporate governance in the region as one of the causes of the crisis. Deficient firm-level governance practices led to the collapse 
of the Thai Baht (Alba et al., 1998). This prompted the government and private sectors to undertake necessary codes of practice and analyze the governance impact on financial outcome (Hodgson et al., 2011). Eventually, in 1999, the Thai Institute of Directorship Association (IOD) was established with an aim for promotion of professionalism in directorship, and it has published the Corporate Governance Report of Thai listed companies since 2001. The report is based on the international governance standards set by the Organization for Economic Cooperation and Development (OECD). This study employs the unique governance score given to each listed firm by the IOD.

\section{LITERATURE REVIEW}

Gompers et al. (2003) pioneered a holistic approach to analyze a relationship between corporate governance and its effect on stock returns. They constructed the Governance Index, or alternatively called GIM Index, employing 24 provisions that limit or protect shareholder rights. According to the score of the index, firms with the weak shareholder protection are grouped to the Dictatorship portfolio, whereas those with the strong shareholder rights are included in the Democracy portfolio. Their results show that the Democracy portfolio outperformed the Dictatorship portfolio with statistical significance. However, when the sample period is divided into two, the outperformance of the Democracy portfolio loses the statistical significance, which hints that the effect of good governance on expected returns can be period-specific and non-linear.

Bebchuk et al. (2008) narrowed down the constituents of the GIM Index and identified 6 governance provisions, labeled as the E-Index (Entrenchment Index), that significantly relates to the negative correlation with firm value and stock returns. Because it is costly to adapt a number of practices, fewer provisions are beneficial to both corporate managers and investors. The E-Index appears to possess explanatory force for abnormal stock returns. The long-short portfolios, which are buying good governance stocks with the E-Index equal to 0 and/or 1 and selling bad governance firms with the E-Index ranging from 3 to 6 , generate positive monthly returns in the tested period. The authors do not show the results for breakdown of shorter periods of time, but the positive alpha from the E-Index is statistically significant not only for the period tested in Gompers et al. (2003), but also for the extended period in the early the 2000s.

On the contrary, Bhagat and Bolton (2008) argue that GIM index and the E-Index do not explain abnormal expected stock returns. Once the endogeneity of the relationship among corporate governance, performance, capital structure, and ownership structure is taken into account, the explanatory power of the governance index for stock return disappears. Core et al. (2006) also state that the weak shareholder protection does not cause lower expected returns. Negative influences of poor governance are already priced in the analysts' prediction. Therefore, there should not be any surprise on the day of earning announcement. Moreover, they assert that the positive relationship between corporate governance and excess stock returns of Gompers et al. (2003) is period-specific. In the period of Dotcom clash from 2000 to 2003, the Dictatorship portfolio actually posts higher returns than the Democracy portfolio even after controlling Fama and French's 3-factor (1993) and momentum factor (Carhart, 1997). Similar inconstant relationship between corporate governance and stock returns is found in other markets such as Germany (Drobetz et al., 2004) and the UK and the European market as a whole (Bauer et al., 2003). The results of Ammann et al. (2011) are based on 22 different developed countries and demonstrate some degree of consistency of corporate governance's positive influence on firm value. Nonetheless, their sample data is only 5 years, which can be argued rather short.

Because of weaker legal protections in the emerging markets, firm-level corporate governance may serve as the alternative to inadequate law enforcements (Klapper \& Love, 2004). Good corporate governance practices are considered valuable intangible assets, particularly in the emerging markets, since controlling shareholders tend to expropriate from minority shareholders in an environment with less investor protection (La Porta et al., 2002; Nenova, 2003). Durnev and Kim (2005) presents that a mixed result on the 
relationship between firm value and corporate governance in the US market is due to the effect of legal environment because of the strong legal structure in the US.

A number of studies on the relation between corporate governance and firm value in the emerging market have been conducted, including Korea (Black et al., 2006), Turkey (Ararat et al., 2016), Russia (Black, 2001; Black et al., 2006), India (Balasubramanian et al., 2010; Saggar \& Singh, 2017), Hong Kong (Cheung et al., 2007, 2011; Lo \& Kwan, 2017), Ukraine (Zheka, 2006), South Africa (Dzingai \& Fakoya, 2017), and Thailand (Wiwattanakantang, 2001; Hodgson et al., 2011; Connelly et al., 2012). What these prior researches have in common is that a good corporate governance positively affects firm value and operating performance in the emerging markets. However, none of these literatures points out time-varying characteristics of the relation between corporate governance and its effect on stock returns. Perhaps due to insufficient data, most researches in the developing markets are based on single-year cross sectional regression. This study analyzes the relationship using time-series data to examine the presence of time-varying features.

\section{DATA AND METHODOLOGY}

The sample universe of this study is all the stocks listed on the Stock Exchange of Thailand (SET). REITs (Real Estate Investment Trust), property funds, and infrastructure funds are excluded. The corporate governance ratings are taken from the "Corporate Governance of Thai Listed Companies", an annual report published by the Thai Institute of Directors (IOD). The IOD examines each listed company on the SET according to a predetermined set of governance criteria and scores them 0-100. The numerical scores are not disclosed, but each company is given the corporate governance stars, as shown in Table 1 . There are five areas to be assessed: Rights of Shareholders, Equitable Treatment of Shareholders, Role of Stakeholders, Disclosure and Transparency, and Board Responsibilities. The sample period is from 2008 to 2015 for 8 years.
Table 1. CG (corporate governance) star by the IOD (Thai Institute of Directors)

\begin{tabular}{l|c|c}
\hline \multicolumn{1}{c}{ Score range } & Number of stars & Description \\
\hline $90-100$ & $* * * * *$ & Excellent \\
\hline $80-90$ & $* * * *$ & Very good \\
\hline $70-79$ & $* * *$ & Good \\
\hline $60-69$ & $* *$ & Satisfactory \\
\hline $50-59$ & $*$ & Pass \\
\hline Less than 50 & No star given & - \\
\hline
\end{tabular}

In order to examine the relationship between the CG star and stock returns, the following cross-sectional equation and time-series mean coefficient is tested with Fama-Macbeth (1973) regression (Gompers et al., 2003; Drobetz et al., 2004; Core et al., 2006, and others) and fixed effects regressions (Ammann et al., 2011):

$$
\begin{aligned}
& \breve{R}_{i, t+2, t+1}=\alpha+\beta_{1} \text { Dummy }_{\text {Excellent }_{i t}}+ \\
& +\beta_{2} \text { Dummy }_{\text {VeryGood }_{i t}}+\beta_{3} \text { Dummy }_{\text {Good }_{i t}}+ \\
& +\beta_{4} \text { LnASSETS }_{i t-1}+\beta_{5} \text { LEV }_{i t-1}+ \\
& +\beta_{6} \frac{\text { CAPEX }_{\text {ASSETS }}}{\text { ASt-1 }_{i t}}+\beta_{7} \text { SALESG }_{i t-1}+ \\
& +\beta_{8} \text { ROA }_{i t-1}+\beta_{9} \text { LnFIRMAGE }_{i t+1}+ \\
& +\beta_{10} \text { BM }_{i t+1}+\beta_{11} \text { ID }_{i t+1}+\varepsilon_{t},
\end{aligned}
$$

where $\breve{R}_{i, t+2, t+1}$ is monthly geometric average return of stock $i$ from January of year $t+1$ to January of year $t+2$, dummy variables take 1 or 0 according to CG rating of each stock $t$, LnASSETS $_{i t-1}$ is the log of book value of assets (in thousands) of stock $i$ in year $t-1, L E V_{i t-1}$ is the ratio of total debt to assets of stock $i$ in year $t-1$, CAPEX / ASSETS ${ }_{i t-1}$ denotes the capital expenditure to assets of stock $i$ in year $t-1$, $S A L E S G_{i t-1}$ is an average past 3-year sales growth rate of stock $i$ in year $t-1, t, R O A_{i t-1}$ is return on assets for stock $i$ in year $t-1, L n F I R M A G E_{i t+1}$ is the $\log$ of the number of years since the establishment for firm $i$ in year $t+1, B M_{i t+1}$ is bookto-market ratio of stock $t$ in January of year $t+1$, $I D_{i t}$ is a vector of industry dummies according to the Industry Classification Benchmark (ICB), and $\varepsilon_{t}$ is an error term. All the stock information is obtained from Thomson Reuters' Datastream.

The IOD releases the annual report in the last quarter of the year. In order for investors to have ample time to access the information, as well as to avoid look- 
ahead bias, the newly-released CG rating is reflected in January of the following year. Thus, after the CG rating is published in year $t$, the return of stock is calculated from January in year $t+1$ to January in year $t+2$. In Thailand, all the listed companies are required to submit the year-end financial statements within three months from the end of the accounting period. Therefore, in January of year $t+1$, all the accounting related information of year $t$ is not available to the public. For this reason, in the regression analysis, the log of total assets, leverage ratio, capital expenditure-to-sales ratio, sales growth ratio, and return on assets are lagged one year. Book-to-market is calculated by dividing market capitalization of a stock in January of year $t+1$ by book value of the stock of year $t-1$.

Prior researches indicate that some firm-level characteristics are related to equity return and corporate governance. In order to avoid the likely extent of omitted variable bias, several control variables are included in the regression. The log of firms' total assets is included as a control variable because larger firms tend to have a higher rating on the governance level (Gompers et al., 2003; Drobetz et al., 2004). Bigger corporations get more exposure to the public. Hence, they have more incentives to retain a higher standard of corporate governance to prevent scandals, as well as keep a good public image. Following Drobetz et al. (2004), Black et al. (2006), and Bebchuk et al. (2008), firms' leverage ratio, measured by debt-to-assets ratio in this study, is controlled. Leverage possibly affects firms' governance practice (Black et al., 2006), and governance has an influence on firms' access to credit (Bhojraj \& Sengupta, 2003). To control endogenous factor of growth opportunities, the past 3 -years' sales growth ratio is included in the equation. Drobetz et al. (2004) write that growth firms desire access to capital markets to raise additional funds to keep expanding their business. The level of capital expenditure, estimated by capital expenditure by total assets, is controlled, as Gompers et al. (2003) report that firms with higher governance practices have higher capital expenditure. Return on assets, labeled as $R O A$, is proxy for profitability, which is likely to have direct effects on stock returns. Among other variables, $R O A$ is more powerful measure of operating performance (Barber \& Lyon, 1996). The log of firms' number of years listed on the market, labeled as LnFIRMAGE, is added to the control variables (Bauer et al., 2003, and others). Governance practic- es of older firms are different from those of younger firms (Black et al., 2006). Most studies find that the coefficients of this variable to be negative, because younger firms are more likely to grow faster (Ararat et al., 2016). Book-to-market ratio (Fama \& French, 1993) is included in the regression. This ratio remains as one of the most powerful explanatory factors for stock returns. Finally, industry group is controlled, because there is always a possibility that firm's corporate governance rating merely reflects an industry that the firm belongs to (Bebchuk et al., 2008). That is, it happens that better governance ratings are more common in certain industries.

Table 2 reports descriptive statistics for all the variables for the full sample period between 2008 and 2015. The mean of the monthly geometric mean stock return is positive at 1.60 , while the median is 1.22 . The maximum return is 12.84 , while the minimum is -7.44 . These suggest that stock returns in the sample period are skewed to the right, which is normal for stock return distribution. Although not reported in the table, the skewness of the stock return is 0.48 . Among the all control variables, sales growth ratio shows the greatest cross-sectional variation with the standard deviation of 23.77. This might be due to the fact that the sample firms include small cap firms, of which some of those small firms' sales growth can be unpredictably high or low in some years.

Table 2. Descriptive statistics

\begin{tabular}{|c|c|c|c|c|c|c|c|}
\hline Variables & Mean & SD & Min & Q1 & Median & Q3 & Max \\
\hline $\begin{array}{l}\text { Monthly } \\
\text { Geometric } \\
\text { Mean Stock } \\
\text { Return }(\widetilde{R})\end{array}$ & 1.60 & 3.27 & -7.44 & -0.43 & 1.22 & 3.44 & 12.84 \\
\hline $\begin{array}{l}\text { Log of Total } \\
\text { Assets } \\
\text { (LnASSETS) }\end{array}$ & 15,15 & 1.73 & 6.91 & 13.95 & 14.88 & 16.07 & 21.76 \\
\hline Leverage (LEV) & 24.24 & 0.26 & 0.00 & 2.00 & 20.27 & 39.61 & 584.10 \\
\hline $\begin{array}{l}\text { Capital } \\
\text { Expenditure to } \\
\text { Assets } \\
\text { CAPEX / ASSETS }\end{array}$ & 5.73 & 8.45 & 0.00 & 0.85 & 2.97 & 7.16 & 90.60 \\
\hline $\begin{array}{l}\text { Average 3-yr } \\
\text { Sales Growth } \\
\text { (SALESG) }\end{array}$ & 8.24 & 23.77 & 79.10 & -1.87 & 6.15 & 14.26 & 267.20 \\
\hline $\begin{array}{l}\text { Return on } \\
\text { Assets }(R O A)\end{array}$ & 5.96 & 10.55 & 80.25 & 2.07 & 6.05 & 10.22 & 97.18 \\
\hline $\begin{array}{l}\text { Log of Firm Age } \\
(L n F I R M A G E)\end{array}$ & 3.02 & 0.79 & 0.00 & 2.30 & 3.26 & 3.61 & 4.70 \\
\hline $\begin{array}{l}\text { Book-to-Market } \\
(B M)\end{array}$ & 0.87 & 1.04 & 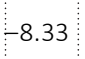 & 0.45 & 0.78 & 1.23 & 5.00 \\
\hline
\end{tabular}

Notes: This table reports the mean, standard deviation, minimum, 1st quartile, median, 3rd quartile, maximum of all the variables in the equation (1). The data are from 2008 to 2015. Monthly Mean Stock Return, Leverage, Capital Expenditure to Assets, Average Sales Growth, Return on Assets are in percentage. 


\section{RESULTS}

The results of the equation (1) are reported in Table 3. The results for industry dummy variables are omitted from the table. The time-series mean of the dummy variables for Excellent and Very Good take positive significant coefficients, whereas that for Good does not, suggesting that only CG ratings with Very Good or higher can lead to higher expected return. However, the dummy variables for Excellent do not get statistical significance in the cross-sectional regressions. There are even two years that the dummy for Excellent gets negative coefficients without significance. The Very Good dummy gets the positive significance only in 2008 . The outcome confirms inconsistent influence of the CG ratings on the stock returns. Receiving a high score on the CG ratings does not always result in higher returns.
Besides the CG dummy variables, $R O A$ and bookto-market show significant positive coefficients in the time-series mean. The coefficient of $B M$ is 0.946 with strong significance, which indicates powerful effect on stock return.

The results of cross-sectional regressions and time-series mean in Table 3 show that the effect of the CG ratings is not constant but rather time-varying. However, that assumption was made based on only 8 years of data, which is not sufficient enough to conclude the time-varying characteristics. Alternatively, parameters of the CG ratings are estimated using fixed effect regression and then the parameters are compared by $z$-test for difference. Table 4 reports the results of the fixed effects regression. $Z$-test is conducted for a null hypothesis that there is no difference in the coefficients between any pair of parameters.

Table 3. Corporate governance by dummy variable and stock returns with industry dummies

\begin{tabular}{|c|c|c|c|c|c|c|c|c|c|}
\hline Year & 2008 & 2009 & 2010 & 2011 & 2012 & 2013 & 2014 & 2015 & Time-series mean \\
\hline Constant & $\begin{array}{l}-2.966 \\
(-1.41)\end{array}$ & $\begin{array}{l}-1.612 \\
(-0.87)\end{array}$ & $\begin{array}{l}-1.336 \\
(-0.79)\end{array}$ & $\begin{array}{l}4.473 \\
(1.95)\end{array}$ & $\begin{array}{c}5.465^{* *} \\
(2.99)\end{array}$ & $\begin{array}{c}6.68 * * * \\
(3.38)\end{array}$ & $\begin{array}{l}-3.017 \\
(-1.31)\end{array}$ & $\begin{array}{l}0.319 \\
(0.17)\end{array}$ & $\begin{array}{l}0.734 \\
(0.53)\end{array}$ \\
\hline Dummy_Excellent & $\begin{array}{l}1.142 \\
(1.34)\end{array}$ & $\begin{array}{l}-0.008 \\
(-0.01)\end{array}$ & $\begin{array}{l}0.903 \\
(1.83)\end{array}$ & $\begin{array}{l}0.742 \\
(1.01)\end{array}$ & $\begin{array}{l}0.173 \\
(0.32)\end{array}$ & $\begin{array}{l}-0.278 \\
(-0.51)\end{array}$ & $\begin{array}{l}0.386 \\
(0.47)\end{array}$ & $\begin{array}{c}0.147 \\
(0.291)\end{array}$ & $\begin{array}{l}0.396^{*} \\
(2.23)\end{array}$ \\
\hline $\begin{array}{l}\text { Dummy_} \\
\text { VeryGood }\end{array}$ & $\begin{array}{c}1.418^{* *} \\
(3.17)\end{array}$ & $\begin{array}{l}0.421 \\
(1.19)\end{array}$ & $\begin{array}{l}0.509 \\
(1.33)\end{array}$ & $\begin{array}{l}0.525 \\
(1.10)\end{array}$ & $\begin{array}{l}0.164 \\
(0.44)\end{array}$ & $\begin{array}{l}-0.005 \\
(-0.01)\end{array}$ & $\begin{array}{l}0.698 \\
(1.45)\end{array}$ & $\begin{array}{l}0.479 \\
(1.46)\end{array}$ & $\begin{array}{c}0.485^{* * *} \\
(4.66)\end{array}$ \\
\hline Dummy_Good & $\begin{array}{l}0.677 \\
(1.80)\end{array}$ & $\begin{array}{l}-0.057 \\
(-0.14)\end{array}$ & $\begin{array}{l}0.307 \\
(0.79)\end{array}$ & $\begin{array}{l}0.031 \\
(0.07)\end{array}$ & $\begin{array}{l}-0.400 \\
(-1.14)\end{array}$ & $\begin{array}{l}-0.285 \\
(-0.71)\end{array}$ & $\begin{array}{l}0.327 \\
(0.81)\end{array}$ & $\begin{array}{l}-0.379 \\
(-1.10)\end{array}$ & $\begin{array}{l}0.042 \\
(0.34)\end{array}$ \\
\hline LnASSETS & $\begin{array}{c}0.256^{*} \\
(2.08)\end{array}$ & $\begin{array}{l}0.180 \\
(1.65)\end{array}$ & $\begin{array}{l}-0.005 \\
(-0.05)\end{array}$ & $\begin{array}{c}-0.288^{*} \\
(-2.23)\end{array}$ & $\begin{array}{c}-0.330^{* *} \\
(-3.24)\end{array}$ & $\begin{array}{c}-0.266^{*} \\
(-2.45)\end{array}$ & $\begin{array}{l}-0.058 \\
(-0.45)\end{array}$ & $\begin{array}{c}0.192^{*} \\
(1.98)\end{array}$ & $\begin{array}{l}-0.014 \\
(-0.16)\end{array}$ \\
\hline LEV & $\begin{array}{l}0.004 \\
(0.52)\end{array}$ & $\begin{array}{l}-0.005 \\
(-0.76)\end{array}$ & $\begin{array}{l}-0.001 \\
(-0.25)\end{array}$ & $\begin{array}{l}0.010 \\
(1.27)\end{array}$ & $\begin{array}{l}-0.000 \\
(-0.08)\end{array}$ & $\begin{array}{l}0.003 \\
(0.52)\end{array}$ & $\begin{array}{c}0.019 * \\
(2.27)\end{array}$ & $\begin{array}{l}0.010 \\
(1.60)\end{array}$ & $\begin{array}{l}0.004 \\
(1.45)\end{array}$ \\
\hline$\frac{C A P E X}{A S S E T S}$ & $\begin{array}{l}0.031 \\
(1.40)\end{array}$ & $\begin{array}{l}0.016 \\
(0.65)\end{array}$ & $\begin{array}{l}-0.001 \\
(-0.06)\end{array}$ & $\begin{array}{l}-0.012 \\
(-0.54)\end{array}$ & $\begin{array}{l}-0.017 \\
(-0.82)\end{array}$ & $\begin{array}{l}-0.004 \\
(-0.25)\end{array}$ & $\begin{array}{c}0.052 * \\
(2.47)\end{array}$ & $\begin{array}{l}0.029 \\
(1.24)\end{array}$ & $\begin{array}{l}0.007 \\
(1.05)\end{array}$ \\
\hline SALESG & $\begin{array}{l}0.000 \\
(0.04)\end{array}$ & $\begin{array}{l}-0.003 \\
(-0.42)\end{array}$ & $\begin{array}{l}-0.001 \\
(-0.21)\end{array}$ & $\begin{array}{l}0.013 \\
(1.44)\end{array}$ & $\begin{array}{l}-0.002 \\
(-0.48)\end{array}$ & $\begin{array}{c}0.021^{* *} \\
(2.94)\end{array}$ & $\begin{array}{c}-0.026 * * \\
(-2.92)\end{array}$ & $\begin{array}{l}0.003 \\
(0.58)\end{array}$ & $\begin{array}{l}0.001 \\
(0.36)\end{array}$ \\
\hline ROA & $\begin{array}{l}0.020 \\
(0.04)\end{array}$ & $\begin{array}{c}0.055^{* *} \\
(2.90)\end{array}$ & $\begin{array}{c}0.033^{*} \\
(2.24)\end{array}$ & $\begin{array}{l}0.011 \\
(0.57)\end{array}$ & $\begin{array}{l}-0.013 \\
(-0.99)\end{array}$ & $\begin{array}{l}-0.011 \\
(-0.74)\end{array}$ & $\begin{array}{c}0.103^{* * *} \\
(4.77)\end{array}$ & $\begin{array}{l}0.022 \\
(1.68)\end{array}$ & $\begin{array}{c}0.028^{* *} \\
(2.89)\end{array}$ \\
\hline LnFIRMAGE & $\begin{array}{l}-0.134 \\
(-0.75)\end{array}$ & $\begin{array}{l}0.205 \\
(1.13)\end{array}$ & $\begin{array}{l}0.170 \\
(0.98)\end{array}$ & $\begin{array}{l}0.271 \\
(1.11)\end{array}$ & $\begin{array}{l}-0.039 \\
(-0.19)\end{array}$ & $\begin{array}{c}-0.462 * \\
(-1.99)\end{array}$ & $\begin{array}{l}-0.026 \\
(-0.09)\end{array}$ & $\begin{array}{c}-0.839 * * * \\
(-3.64)\end{array}$ & $\begin{array}{l}-0.123 \\
(-1.05)\end{array}$ \\
\hline BM & $\begin{array}{c}1.058^{* * *} \\
(7.32)\end{array}$ & $\begin{array}{c}1.04 * * * \\
(5.84)\end{array}$ & $\begin{array}{c}0.658^{* *} \\
(2.88)\end{array}$ & $\begin{array}{c}1.044^{* * *} \\
(3.39)\end{array}$ & $\begin{array}{l}0.549 \\
(1.69)\end{array}$ & $\begin{array}{c}1.325^{* * *} \\
(5.08)\end{array}$ & $\begin{array}{c}1.962^{* * *} \\
(4.80)\end{array}$ & $\begin{array}{c}1.201^{* * *} \\
(4.77)\end{array}$ & $\begin{array}{c}1.017^{* * *} \\
(8.94)\end{array}$ \\
\hline Industry dummies & Yes & Yes & Yes & Yes & Yes & Yes & Yes & Yes & Yes \\
\hline
\end{tabular}

Notes: The following equation is tested with cross-sectional regression and time-series mean is tested with Fama-Macbeth (1973) regression model.

$$
\begin{aligned}
& \breve{R}_{i, t+2, t+1}=\alpha+\beta_{1} \text { Dummy }_{\text {Excellent }_{t t}}+\beta_{2} \text { Dummy }_{\text {VeryGood }_{i t}}+\beta_{3} \text { Dummy }_{\text {Good }_{i t}}+\beta_{4} \text { LnASSETS }_{i t-1}+\beta_{5} \text { LEV }_{i t-1}+ \\
& +\beta_{6} \frac{\text { CAPEX }}{\text { ASSETS }_{i t-1}}+\beta_{7} \text { SALESG }_{i t-1}+\beta_{8} \text { ROA }_{i t-1}+\beta_{9} \text { LnFIRMAGE }_{i t+1}+\beta_{10} \text { BM }_{i t+1}+\beta_{11} I_{i t+1}+\varepsilon_{t},
\end{aligned}
$$

where $\breve{R}$ is mothly geometric mean stock return, dummy variables take 1 or 0 according to CG rating of each stock, LnASSETS is log of assets, CAPEX / ASSETS is capital expenditure to assets, SALESG is an average past 3-year sales growth, ROA is return on assets, LnFIRMAGE is log of firm age, $B M$ is book-to-market, $I D$ is industry dummy variable. Industry grouping is according to the Industry Classification Benchmark (ICB). There are actually 10 industry groups, but the results for each industry dummy are omitted from this table. The data are from 2008 to 2015. Standard error for the coefficients are in the parentheses. $*, * *$, and $* * *$ indicate significance at $0.05,0.01$, and 0.001 level, respectively. 
The Excellent dummies get positive significance in 2008 and 2010, and surprisingly, negative significance in 2013. $Z$-test for coefficient difference confirms that the parameter in 2008 is statistically different from that of the rest of years, except in 2010 , perhaps because the both years get the positive significant coefficients. The negative parameter in 2013 differs significantly from those from 2008 to 2011. The contrast of the CG rating's effect on the stock return is an obvious sign of time-varying characteristics.

The result for the Very Good dummies is similar to the one for the Excellent dummies. The dummies from 2008 to 2010 are positively significant and those from 2012 and 2013 are negative but without significance. The parameter in 2008 is statistically different from every year in the sample. Although the parameters in 2009 and 2010 are also significantly positive, that in 2008 is still different from the two years, which means that the positive magnitude that the CG rating in 2008 affects stock returns is higher than the CG ratings in 2009 and 2010. This is also an indication of time-varying characteristics of the CG score. The negative coefficient in 2013 gets significant $z$-score when tested with the years from 2008 to 2011 . This shows the negative effect on stock returns in 2013 is a distinctive and unique impact, which signals inconsistency of the CG rating's power.

The Good dummies represent weaker influence on stock returns. Only in 2008 gets the significant parameter. $Z$-test for coefficient difference reveals that the positive parameter in 2008 statistically differs from those in 2012, 2013, and 2015, which are all negative.

$R O A$ and book-to-market show significantly positive influence on stock return in the fixed effect regression, while other control variables are all insignificant.

Table 4. Fixed effects regression of stock returns on corporate governance by dummy variables with industry dummy variables

\begin{tabular}{|c|c|c|c|c|c|c|c|c|c|}
\hline Dependent variable & $\begin{array}{l}\text { Stock } \\
\text { returns }\end{array}$ & $\begin{array}{l}\text { Z-test for } \\
\text { coefficients } \\
\text { difference }\end{array}$ & 2009 & 2010 & 2011 & 2012 & 2013 & 2014 & 2015 \\
\hline Dummy_Excellent 2008 & $\begin{array}{c}2.231^{* * *} \\
(3.32)\end{array}$ & - & $\begin{array}{l}1.92 * \\
(0.02)\end{array}$ & $\begin{array}{c}1.38 \\
(0.08)\end{array}$ & $\begin{array}{l}1.86^{*} \\
(0.03)\end{array}$ & $\begin{array}{c}3.32 * * * \\
(0.00)\end{array}$ & $\begin{array}{c}3.99 * * * \\
(0.00)\end{array}$ & $\begin{array}{c}2.84^{* *} \\
(0.00)\end{array}$ & $\begin{array}{l}2.61^{* *} \\
(0.00)\end{array}$ \\
\hline Dummy_Excellent 2009 & $\begin{array}{l}0.643 \\
(1.34)\end{array}$ & - & - & $\begin{array}{l}-0.62 \\
(0.73)\end{array}$ & $\begin{array}{c}0.00 \\
(0.49)\end{array}$ & $\begin{array}{l}1.74^{*} \\
(0.04)\end{array}$ & $\begin{array}{c}2.49 * * \\
(0.00)\end{array}$ & $\begin{array}{c}1.25 \\
(0.10)\end{array}$ & $\begin{array}{c}0.83 \\
(0.20)\end{array}$ \\
\hline Dummy_Excellent 2010 & $\begin{array}{c}1.077^{*} \\
(2.17)\end{array}$ & - & - & - & $\begin{array}{c}0.58 \\
(0.27)\end{array}$ & $\begin{array}{l}2.31^{*} \\
(0.01)\end{array}$ & $\begin{array}{c}3.09 * * \\
(0.00)\end{array}$ & $\begin{array}{l}1.79 * \\
(0.03)\end{array}$ & $\begin{array}{c}1.44 \\
(0.07)\end{array}$ \\
\hline Dummy_Excellent 2011 & $\begin{array}{l}0.595 \\
(1.57)\end{array}$ & - & - & - & - & $\begin{array}{l}1.66^{*} \\
(0.04)\end{array}$ & $\begin{array}{c}2.36^{* *} \\
(0.00)\end{array}$ & $\begin{array}{c}1.19 \\
(0.11)\end{array}$ & $\begin{array}{c}0.78 \\
(0.21)\end{array}$ \\
\hline Dummy_Excellent 2012 & $\begin{array}{l}-0.591 \\
(-1.13)\end{array}$ & - & - & - & - & - & $\begin{array}{c}0.58 \\
(0.27)\end{array}$ & $\begin{array}{l}-0.37 \\
(0.64)\end{array}$ & $\begin{array}{l}-0.95 \\
(0.83)\end{array}$ \\
\hline Dummy_Excellent 2013 & $\begin{array}{c}-0.997^{*} \\
(-2.21)\end{array}$ & - & - & - & - & - & - & $\begin{array}{l}-0.94 \\
(0.82)\end{array}$ & $\begin{array}{r}-1.64 * \\
(0.95)\end{array}$ \\
\hline Dummy_Excellent 2014 & $\begin{array}{l}-0.300 \\
(-0.514)\end{array}$ & - & - & - & - & - & - & - & $\begin{array}{l}-0.50 \\
(0.69)\end{array}$ \\
\hline Dummy_Excellent 2015 & $\begin{array}{l}0.082 \\
(0.17)\end{array}$ & - & - & - & - & - & - & - & - \\
\hline Dummy_Very Good 2008 & $\begin{array}{c}1.627^{* * *} \\
(4.44)\end{array}$ & - & $\begin{array}{l}1.95^{*} \\
(0.02)\end{array}$ & $\begin{array}{l}1.75^{*} \\
(0.03)\end{array}$ & $\begin{array}{l}2.00^{*} \\
(0.02)\end{array}$ & $\begin{array}{c}3.30 * * * \\
(0.00)\end{array}$ & $\begin{array}{c}3.75 * * * \\
(0.00)\end{array}$ & $\begin{array}{l}2.14^{*} \\
(0.01)\end{array}$ & $\begin{array}{l}2.54^{* *} \\
(0.00)\end{array}$ \\
\hline Dummy_Very Good 2009 & $\begin{array}{c}0.661^{*} \\
(1.99)\end{array}$ & - & - & $\begin{array}{l}-0.02 \\
(0.50)\end{array}$ & $\begin{array}{c}0.13 \\
(0.44)\end{array}$ & $\begin{array}{c}1.59 \\
(0.05)\end{array}$ & $\begin{array}{l}1.98^{*} \\
(0.02)\end{array}$ & $\begin{array}{c}0.32 \\
(0.37)\end{array}$ & $\begin{array}{c}0.65 \\
(0.25)\end{array}$ \\
\hline Dummy_Very Good 2010 & $\begin{array}{c}0.672^{*} \\
(1.66)\end{array}$ & - & - & - & $\begin{array}{c}0.13 \\
(0.44)\end{array}$ & $\begin{array}{c}1.47 \\
(0.06)\end{array}$ & $\begin{array}{l}1.82^{*} \\
(0.03)\end{array}$ & $\begin{array}{c}0.31 \\
(0.37)\end{array}$ & $\begin{array}{c}0.60 \\
(0.27)\end{array}$ \\
\hline Dummy_Very Good 2011 & $\begin{array}{l}0.595 \\
(1.57)\end{array}$ & - & - & - & - & $\begin{array}{c}1.38 \\
(0.08)\end{array}$ & $\begin{array}{l}1.74^{*} \\
(0.04)\end{array}$ & $\begin{array}{c}0.17 \\
(0.42)\end{array}$ & $\begin{array}{c}0.48 \\
(0.31)\end{array}$ \\
\hline Dummy_Very Good 2012 & $\begin{array}{l}-0.171 \\
(-0.42)\end{array}$ & - & - & - & - & - & $\begin{array}{c}0.28 \\
(0.38)\end{array}$ & $\begin{array}{l}-1.21 \\
(0.88)\end{array}$ & $\begin{array}{l}-0.98 \\
(0.83)\end{array}$ \\
\hline Dummy_Very Good 2013 & $\begin{array}{l}-0.324 \\
(-0.88)\end{array}$ & - & - & - & - & - & - & $\begin{array}{l}-1.56 \\
(0.94)\end{array}$ & $\begin{array}{l}-1.33 \\
(0.90)\end{array}$ \\
\hline Dummy_Very Good 2014 & $\begin{array}{l}0.500 \\
(1.32)\end{array}$ & - & - & - & - & - & - & - & $\begin{array}{c}0.29 \\
(0.38)\end{array}$ \\
\hline Dummy_Very Good 2015 & $\begin{array}{l}0.349 \\
(1.01)\end{array}$ & - & - & - & - & - & - & - & - \\
\hline Dummy_Good 2008 & $\begin{array}{c}0.788^{*} \\
(2.42)\end{array}$ & - & $\begin{array}{c}1.24 \\
(0.10)\end{array}$ & $\begin{array}{c}0.87 \\
(0.19)\end{array}$ & $\begin{array}{c}1.26 \\
(0.10)\end{array}$ & $\begin{array}{l}2.27^{*} \\
(0.01)\end{array}$ & $\begin{array}{c}2.34^{* *} \\
(0.00)\end{array}$ & $\begin{array}{c}1.54 \\
(0.06)\end{array}$ & $\begin{array}{l}2.29^{*} \\
(0.01)\end{array}$ \\
\hline
\end{tabular}


Table 4 (cont.). Fixed effects regression of stock returns on corporate governance by dummy variables with industry dummy variables

\begin{tabular}{|c|c|c|c|c|c|c|c|c|c|}
\hline Dependent variable & $\begin{array}{l}\text { Stock } \\
\text { returns }\end{array}$ & $\begin{array}{l}\text { Z-test for } \\
\text { coefficients } \\
\text { difference }\end{array}$ & 2009 & 2010 & 2011 & 2012 & 2013 & 2014 & 2015 \\
\hline Dummy_Good 2009 & $\begin{array}{l}0.164 \\
(0.42)\end{array}$ & - & - & $\begin{array}{l}-0.28 \\
(0.61)\end{array}$ & $\begin{array}{l}-0.01 \\
(0.50)\end{array}$ & $\begin{array}{c}0.99 \\
(0.15)\end{array}$ & $\begin{array}{c}1.02 \\
(0.15)\end{array}$ & $\begin{array}{c}0.18 \\
(0.42)\end{array}$ & $\begin{array}{c}0.94 \\
(0.17)\end{array}$ \\
\hline Dummy_Good 2010 & $\begin{array}{l}0.325 \\
(0.77)\end{array}$ & - & - & - & $\begin{array}{c}0.27 \\
(0.39)\end{array}$ & $\begin{array}{c}1.23 \\
(0.10)\end{array}$ & $\begin{array}{c}1.26 \\
(0.10)\end{array}$ & $\begin{array}{c}0.47 \\
(0.31)\end{array}$ & $\begin{array}{c}1.19 \\
(0.11)\end{array}$ \\
\hline Dummy_Good 2011 & $\begin{array}{l}0.171 \\
(0.46)\end{array}$ & - & - & - & - & $\begin{array}{c}1.03 \\
(0.15)\end{array}$ & $\begin{array}{c}1.06 \\
(0.14)\end{array}$ & $\begin{array}{c}0.20 \\
(0.41)\end{array}$ & $\begin{array}{c}0.98 \\
(0.16)\end{array}$ \\
\hline Dummy_Good 2012 & $\begin{array}{l}-0.391 \\
(-0.96)\end{array}$ & - & - & - & - & - & $\begin{array}{c}0.00 \\
(0.49)\end{array}$ & $\begin{array}{l}-0.88 \\
(0.81)\end{array}$ & $\begin{array}{l}-0.09 \\
(0.53)\end{array}$ \\
\hline Dummy_Good 2013 & $\begin{array}{l}-0.394 \\
(-1.02)\end{array}$ & - & - & - & - & - & - & $\begin{array}{l}-0.91 \\
(0.82)\end{array}$ & $\begin{array}{l}-0.10 \\
(0.54)\end{array}$ \\
\hline Dummy_Good 2014 & $\begin{array}{l}0.070 \\
(0.21)\end{array}$ & - & - & - & - & - & - & - & $\begin{array}{c}0.82 \\
(0.20)\end{array}$ \\
\hline Dummy_Good 2015 & $\begin{array}{l}-0.340 \\
(-0.92)\end{array}$ & - & - & - & - & - & - & - & - \\
\hline LnASSETS & $\begin{array}{l}0.002 \\
(0.07)\end{array}$ & $\frac{C A P E X}{A S S E T S}$ & $\begin{array}{l}0.005 \\
(0.79)\end{array}$ & ROA & $\begin{array}{c}0.028^{* * *} \\
(5.01)\end{array}$ & BM & $\begin{array}{c}1.010 * * * \\
(14.36)\end{array}$ & - & - \\
\hline LEV & $\begin{array}{l}0.004 \\
(1.65)\end{array}$ & SALESG & $\begin{array}{l}0.002 \\
(0.81)\end{array}$ & LnFIRMAGE & $\begin{array}{l}-0.068 \\
(-0.94)\end{array}$ & $\begin{array}{l}\text { Industry } \\
\text { dummies }\end{array}$ & Yes & - & - \\
\hline
\end{tabular}

Notes: The following equation is tested with fixed effect regression model.

$\breve{R}_{i, t+2, t+1}=\beta_{1}$ Dummy $_{\text {Excellent } 2008}+\beta_{2}$ Dummy $_{\text {Excellent } 2009}+\beta_{3}$ Dummy Excellent $2010+\beta_{4}$ Dummy Excellent 2011 +

$+\beta_{5}$ Dummy Excellent $2012+\beta_{6}$ Dummy ${ }_{\text {Excellent } 2013}+\beta_{7}$ Dummy $y_{\text {Excellent } 2014}+\beta_{8}$ Dummy $_{\text {Excellent } 2015}+$

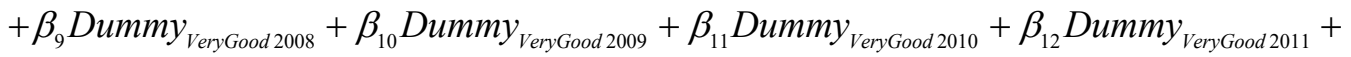

$+\beta_{13}$ Dummy $y_{\text {VeryGood } 2012}+\beta_{14}$ Dummy $y_{\text {VeryGood } 2013}+\beta_{15}$ Dummy $_{\text {VeryGood } 2014}+\beta_{16}$ Dummy $y_{\text {VeryGood } 2015}+$

$+\beta_{17}$ Dummy $_{\text {Good } 2008}+\beta_{18}$ Dummy $_{\text {Good } 2009}+\beta_{19}$ Dummy $_{\text {Good } 2010}+\beta_{20}$ Dummy ${ }_{\text {Good } 2011}+\beta_{21}$ Dummy $y_{\text {Good } 2012}+$

$+\beta_{22}$ Dummy $_{\text {Good } 2013}+\beta_{23}$ Dummy $_{\text {Good } 2014}+\beta_{24}$ Dummy $_{\text {Good } 2015}+\beta_{25}$ LnASSETS $_{i t-1}++\beta_{26} L_{E V_{i t-1}}+$

$+\beta_{27} \frac{C A P E X}{A S S E T S_{i t-1}}+\beta_{28} S_{A L E S G}+\beta_{i t-1}$ ROA $_{i t-1}+\beta_{30}$ LnFIRMAGE $_{i t+1}+$

$+\beta_{31} B M_{i t+1}+\beta_{32} I D_{i t+1}+\varepsilon_{t}$,

where $\breve{R}$ is mothly geometric mean stock return, dummy variables take 1 or 0 according to CG rating of each stock, LnASSETS is log of assets, CAPEX / ASSETS is capital expenditure to assets, SALESG is an average past 3-year sales growth, $R O A$ is return on assets, $\operatorname{LnFIRMAGE}$ is log of firm age, and $B M$ is book-to-market, $I D$ is industry dummy variable. Industry grouping is according to the Industry Classification Benchmark (ICB). There are actually 10 industry groups, but the results for each industry dummy is omitted from this table. The data are from 2008 to 2015 . Standard error for the coefficients are in the in the parentheses. $*, * *$, and $* * *$ indicate significance at $0.05,0.01$, and 0.0001 level, respectively. $Z$-test is for a null hypothesis that there is no difference in coefficients. $P$-values are in the parentheses. $*, * *$, and $* * *$ indicate significance at $0.05,0.01$, and 0.001 level, respectively.

\section{CONCLUSION}

Since Gompers et al. (2003) first explored the field of the corporate governance index and its effect on increased firm value, a number of researches have been conducted. The literature generally supports the theory that better governance practices positively affect the firms' value creation. Nevertheless, some scholars, including Core et al. (2006), propose opposing views. In a broad sense, the results of this study support both pros and cons of the positive relationship. This research fills the gap and claims that the relationship between the corporate governance and its effect on stock returns is non-linear and time-varying. 
This paper's result of the cross-sectional regression and Fama-Macbeth (1973) regression reveals that, although the time-series parameter mean for the CG rating on stock returns is positive, the relationship is not constant across the tested individual years. In a longer period of time, better corporate governance leads to better expected returns. However, on yearly basis, the positive relationship deteriorates and loses explanatory power in the most of the tested years. The test for the coefficients difference further confirms that the effect of the governance ratings on the stock returns varies year by year. Corporate governance ratings in a particular year has a greater impact on the expected returns than other years.

Future researches can be conducted to discover the reason that such time-varying relationship exists. As Doidge et al. (2007) suggest, it may be due to a high cost associated with implementation of governance practices. Also, as the corporations' responsibilities are not limited to the protection of shareholders rights, social, environmental, and sustainable factors can be included in analysis.

\section{REFERENCES}

1. Alba, P., Claessens, S., \& Djankov, S. (1998). Thailand's Corporate Financing and Governance Structures: Impact on Firms' Competitiveness (Conference on Thailand's Dynamic Economic Recovery and Competitiveness). Bangkok. Retrieved from https:// www.researchgate.net/publication/23549015_Thailand's_Corporate_Financing_and_Governance_ Structures

2. Ammann, M., Oesch, D., \& Schmid, M. (2011). Corporate Governance and Firm Value: International Evidence. Journal of Empirical Finance, 18(1), 36-55. https://doi.org/10.1016/j.jempfin.2010.10.003

3. Ararat, M., Black, B., \& Yurtoglu, B. (2017). The Effect of Corporate Governance on Firm Value and Profitability: Time-Series Evidence from Turkey. Emerging Markets Review, 30, 113-132. https://doi. org/10.1016/j.ememar.2016.10.001

4. Balasubramanian, N., Black, B., \& Khanna, V. (2010). The Relation between Firm-Level Corporate Governance and Market Value: A Case Study of India. Emerging Markets Review, 11(4), 319-340. https://doi.org/10.1016/j.ememar.2010.05.001

5. Barber, B., \& Lyon, J. (1996). Detecting Abnormal Operating Performance: The Empirical Power and Specification of Test Statistics. Journal of Financial Economics, 41(3), 359-399. https://doi.org/10.1016/0304405X(96)84701-5

6. Bauer, R., Guenster, N., \& Otten, R. (2003). Empirical Evidence on Corporate Governance in Europe: The Effect on Stock Return, Firm Value and Performance. Journal of Asset Management, 5(2), 91-104. https://doi.org/10.1057/palgrave. jam.2240131

7. Bebchuk, L., Cohen, A., \& Ferrell, A. (2008). What Matters in Corporate Governance? The Review of Financial Studies, 22(2), 783-827 https://doi.org/10.1093/ rfs/hhn099

8. Bhagat, S., \& Bolton, B. (2008). Corporate Governance and Firm Performance. Journal of Corporate Finance, 14(3), 257-273. https://doi. org/10.1016/j.jcorpfin.2008.03.006

9. Bhojraj, S., \& Sengupta, S. (2003). Effect of Corporate Governance on Bond Ratings and Yields: The Role of Institutional Investors and Outside Directors. Journal of Business, 76(3), 455-475. http:// dx.doi.org/10.1086/344114

10. Black, B. (2001). The Corporate Governance Behavior and Market Value of Russian Firms. Emerging Market Review, 2(2), 89-108. https://doi.org/10.1016/S15660141(01)00012-7

11. Black, B., Jang, H., \& Kim, W. (2006). Does Corporate Governance Affect Firm Value? Evidence from Korea. Journal of Law Economics and Organization,
22(2), 366-413. https://doi. org/10.1093/jleo/ewj018

12. Black, B., Love, I., \& Rachinsky, A. (2006). Corporate Governance Indices and Firms' Market Values: Time Series Evidence from Russia. Emerging Markest Review, 7(4), 361-379. https://doi.org/10.1016/j. ememar.2006.09.004

13. Carhart, M. (1997). On Persistence in Mutual Fund Performance. Journal of Finance, 52(1), 57-82. https://doi. org/10.1111/j.1540-6261.1997. tb03808.x

14. Cheung, Y., Connelly, J., Jiang, P., \& Limpaphayom, P. (2011). Does Corporate Governance Predict Future Performance? Evidence from Hong Kong. Financial Management, 40(1), 159-197. https://doi.org/10.1111/j.1755053X.2010.01138.x

15. Cheung, Y., Connelly, J., Limpaphayom, P., \& Zhou, L. (2007). Do Investors Really Value Corporate Governance? Evidence from Hong Kong Market. Journal of International Financial Management and Accounting, 18(2), 86-122. https://doi.org/10.1111/j.1467646X.2007.01009.x

16. Connelly, J., Limpaphayom, P., \& Nagarajan, N. (2012). Form Versus Substance: The Effect of Ownership Structure and Corporate Governance on Firm Value in Thailand. Journal of Banking and Finance, 36(6), 1722- 
1743. https://doi.org/10.1016/j. jbankfin.2012.01.017

17. Core, J., Guay, W., \& Rusticus, T (2006). Does Weak Governance Cause Weak Stock Returns? An Examination of Firm Operating Performance and Investors' Expectations. Journal of Finance, 61(2), 655-687. https://doi.org/10.1111/j.15406261.2006.00851.x

18. Doidge, C., Kayolyi, A., \& Stulz, R. (2007). Why Do Counties Matter So Much for Corporate Governance? Journal of Financial Economics, 86(1), 1-39. https://doi. org/10.1016/j.jfineco.2006.09.002

19. Drobetz, W., Schillhofer, A., \& Zimmermann, H. (2004). Corporate Governance and Expected Stock Returns: Evidence from Germany. European Financial Management, 10(2), 267-293. https://doi.org/10.1111/ j.1354-7798.2004.00250.x

20. Durnev, A., \& Kim, H. (2005). To Steal or Not to Steal: Firm Attributes, Legal Environment, and Valuation. Journal of Finance, 60(3), 1461-1493. https://doi.org/10.1111/j.15406261.2005.00767.x

21. Dzingai, I., \& Fakoya, M. (2017). Effect of Corporate Governance Structure on Financial Performance of Johannesburg Stock Exchange (JSE)-Listed Mining Firms. Sustainability, 9(6), 1-15. https:// doi.org/10.3390/su9060867

22. Fama, E., \& French, K. (1993). Common Risk Factors in the Returns on Stocks and
Bonds. Journal of Financial

Economics, 33(1), 389-411.

https://doi.org/10.1016/0304405X(93)90023-5

23. Fama, E., \& MacBeth, D. (1973). Risk, Return, and Equilibrium: Empirical Tests. Journal of Political Economy, 81(3), 607-636. http://dx.doi.org/10.1086/260061

24. Gompers, P., Ishii, J., \& Metrick, A. (2003). Corporate Governance and Equity Prices. The Quarterly Journal of Economics, 118(1), 107-156. https://doi. org/10.1162/00335530360535162

25. Hodgson, A., Lhaopadchan, S., \& Buakes, S. (2011). How Informative Is the Thai Corporate Governance Index? A Financial Approach. International Journal of Accounting and Information Management, 19(1), 53-79. https://doi. org/10.1108/18347641111105935

26. Klapper, L., \& Love, I. (2004). Corporate Governance, Investor Protection and Performance in Emerging Markets. Journal of Corporate Finance, 10(5), 703728. https://doi.org/10.1016/ S0929-1199(03)00046-4

27. La Porta, R., Lopez-de-Silanes, F., Shleifer, A., \& Vishny, R. (2002). Investor Protection and Corporate Valuation. Journal of Finance, 57(3), 1147-1170. https://doi.org/10.1111/15406261.00457

28. Lo, K., \& Kwan, C. (2017). The Effect of Environmental, Social, Governance and Sustainability
Initiatives on Stock ValueExamining Market Response to Initiatives Undertaken by Listed Companies. Corporate Social Responsibility and Environmental Management, 24(6), 606-619. https://doi.org/10.1002/csr.1431

29. Nenova, T. (2003). The Value of Corporate Voting Rights and Control: A Cross-Listings in the United States and Subsequent Equity Offerings. Journal of Financial Economics, 68(3), 325351. https://doi.org/10.1016/ S0304-405X(03)00069-2

30. Saggar, R., \& Singh, B. (2017). Corporate Governance and Risk Reporting: Indian Evidence. Managerial Auditing Journal, 32(4/5), 378-405. https://doi. org/10.1108/MAJ-03-2016-1341

31. Wiwattanakantang, Y. (2001). Controlling Shareholders and Corporate Value: Evidence from Thailand. Pacific-Basin Finance Journal, 9(4), 323-362. https://doi.org/10.1016/S0927538X(01)00022-1

32. Zheka, V. (2006). Does Corporate Governance Causally Predict Firm Performance? Panel Data and Instrumental Variables Evidence. Retrieved from https:// papers.ssrn.com/sol3/papers. cfm?abstract_id $=877913$

33. Zhuang, J., Edwards, D., Webb, D., \& Capulong, V. (2000). Corporate Governance and Finance in East Asia: a study of Indonesia, Republic of Korea, Malaysia, Philippines and Thailand. Asian Development Bank. 